Institute of $\mathbf{F}_{\text {ood and }} \mathbf{A}_{\text {gricultural }} \mathbf{S}_{\text {ciences }}$

\title{
Mosquitoes In and Around the Home ${ }^{1}$
}

\section{F. M. Oi and Renee Anderson ${ }^{2}$}

Mosquitoes are familiar and annoying pests of humans and animals. Their rapid wing movement produces a distinctive high-pitched hum, and their bites cause red, itchy welts. Mosquitoes are more than just a nuisance, however, because they also serve as carriers (vectors) of several disease-causing agents.

Mosquitoes are small, slender flies that are members of the family Culicide. When viewed under a hand lens, adult mosquitoes are easily recognizable - scales cover the wing veins and the hind wing margin. The scale and setal (bristle) patterns of the adults are distinctive characteristics for species identification. There are at least 76 known species of mosquitoes in Florida.

\section{Mosquito Biology}

Like butterflies, mosquitoes undergo complete metamorphosis and have egg, larval, pupal, and adult stages (Figure 1). Only the adult females ingest blood. However, not all species are "blood-suckers." The cannibal mosquitoes in the genus Toxorhynchites are large and conspicuous, but they do not bite humans. The larvae of these mosquitoes eat the larvae of other mosquito species. As adults, the Toxorhynchites feed exclusively on nectar and other plant juices.

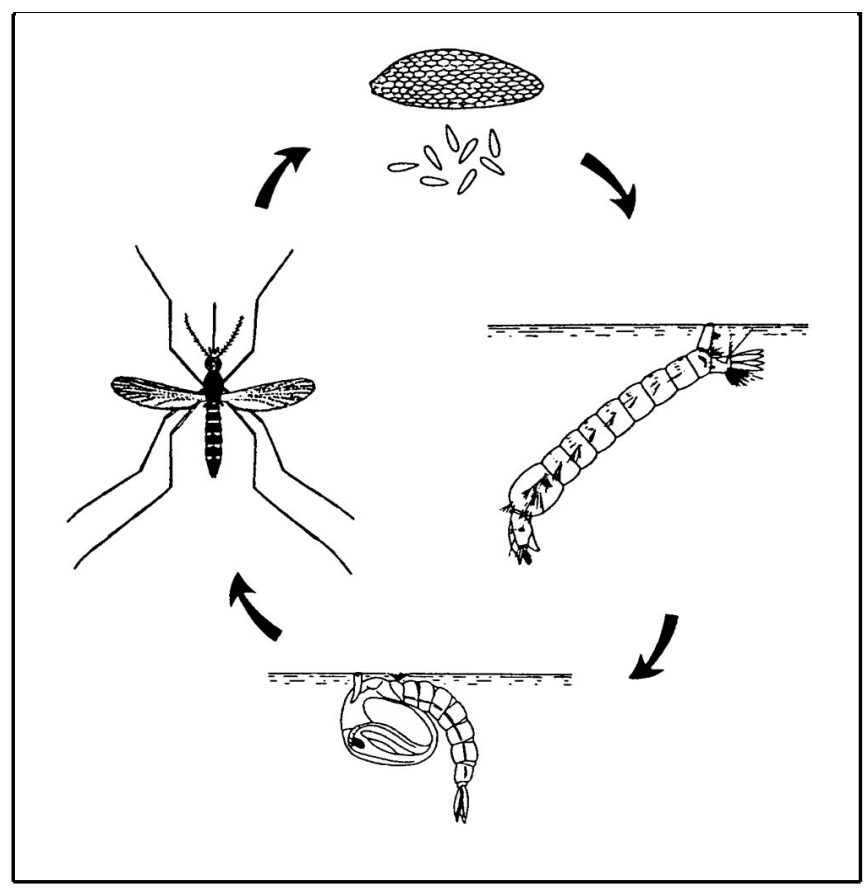

Figure 1. Aedes aegypti mosquito life cycle (eggs-top, larva-right, pupa-bottom, adult-left).

1. This document is ENY-2004, one of a series of the Department of Entomology and Nematology, Florida Cooperative Extension Service, Institute of Food and Agricultural Sciences, University of Florida. Date first printed: February 2003. Please visit the EDIS Website at http://edis.ifas.ufl.edu.

2. F. M. Oi, assistant extension entomologist, Entomology and Nematology Department, Cooperative Extension Service, Institute of Food and Agricultural Sciences, University of Florida, Gainesville, FL 32611 and Renee Anderson, graduate student, Department of Entomology, Auburn University, Auburn, AL.

The use of trade names in this publication is solely for the purpose of providing specific information. UF/IFAS does not guarantee or warranty the products named, and references to them in this publication does not signify our approval to the exclusion of other products of suitable composition. All chemicals should be used in accordance with directions on the manufacturer's label. All chemicals should be used in accordance with directions on the manufacturer's label.

The Institute of Food and Agricultural Sciences is an equal opportunity/affirmative action employer authorized to provide research, educational information and other services only to individuals and institutions that function without regard to race, color, sex, age, handicap, or national origin. For information on obtaining other extension publications, contact your county Cooperative Extension Service office. Florida Cooperative Extension Service/Institute of Food and Agricultural Sciences/University of Florida/Christine Taylor Waddill, Dean. 
Of the blood-sucking mosquito species, a blood meal is usually (but not always) necessary for egg maturation. The eggs may be laid singly or in rafts but always in association with water and where it is quiet and protected. Females may lay up to 100 or 200 eggs per batch and deposit an egg batch every 7 or 10 days. Eggs can take from days to months to hatch. In general, during warm periods and under favorable conditions, eggs will hatch in a few days. However, the eggs of "flood-water" mosquitoes can remain dormant and are capable of surviving for months out of water until they are flooded. Eggs may be laid at the water surface, at the water-soil interface along banks, or on soil or vegetation that is subject to periodic flooding, depending on the species involved. Other sites where eggs may be deposited include tree holes, temporary puddles, freshwater and salt marshes, and containers in which water stands, such as discarded tires, cans, pet water dishes, and bird baths.

The larvae (Figure 2) have no legs and have an enlarged thorax that is much wider than the head and abdomen. Larvae prefer quiet, still water, and are commonly referred to as "wrigglers," which describes their movement in water. They feed on decaying organic matter that includes microorganisms. After hatching, the larva goes through four molts, with the final molt resulting in a pupa. The larval stage typically is completed in about 7 to 10 days.

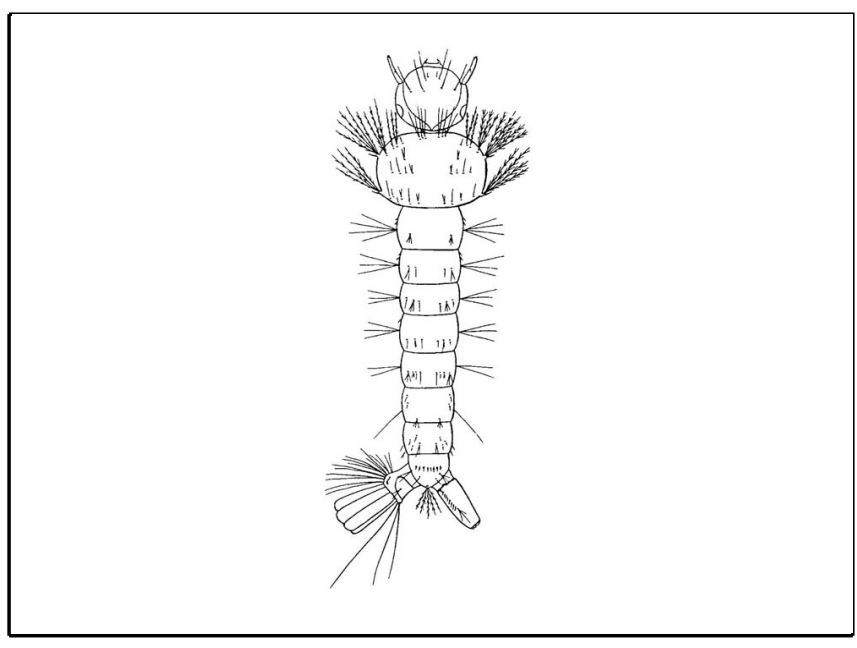

Figure 2. Aedes aegypti mosquito larva.

The pupa is a mobile but nonfeeding stage. The pupae are frequently called "tumblers" because when they are disturbed at the water surface, they will quickly tumble downward and then rise slowly to the water surface. After 2 or 3 days, the pupa molts into the winged adult.

The longevity of the adult (Figure 3) varies greatly. During the heat of summer, most adult females do not live more than 2 weeks. The males have a shorter life span. During both the adult and immature stages, mosquitoes serve as valuable prey to numerous forms of wildlife such as bats, birds, and aquatic animals including sport fish.

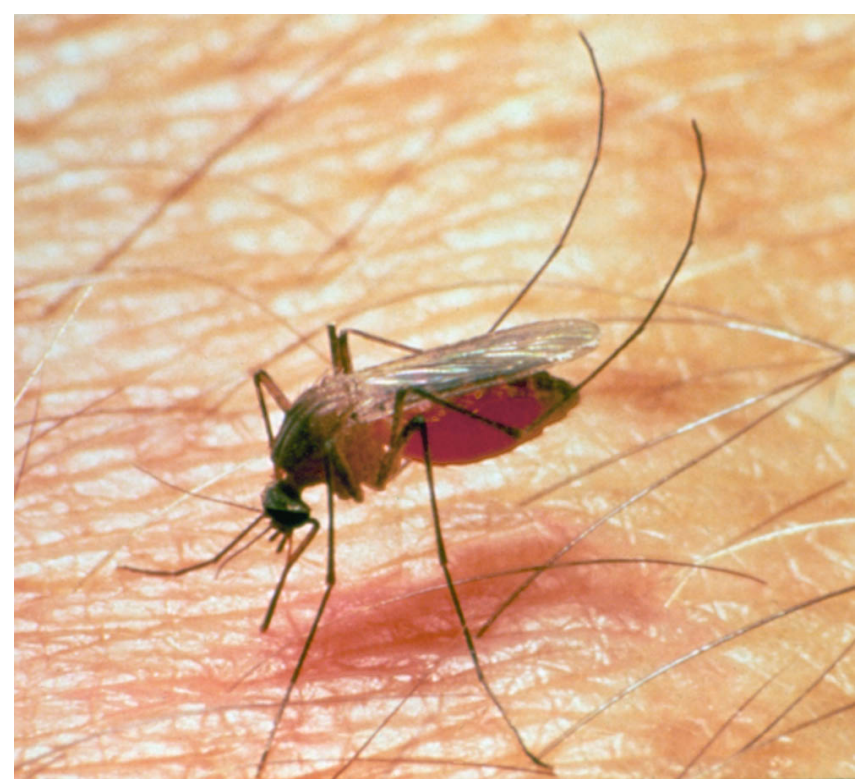

Figure 3. Adult female mosquito (Culex). Credits: J. F. Butler, University of Florida

Although many species (Figure 4) of mosquitoes have a wide geographic distribution in the United States, their local abundance varies greatly. Warmth, precipitation, and favorable microhabitats influence potential population levels of the immature stages. Eggs laid in floodprone sites can accumulate for years until they hatch under favorable environmental conditions, thus resulting in explosive population levels within a relatively short period of time.

\section{Feeding Habits of Adult Mosquitoes}

Initially, mosquitoes use odor and chemical cues to locate their food source. As the mosquito comes near a potential host, moist air from the host and visual cues become important. The chemical cues help the mosquito decide where to land on a host. Carbon dioxide exhaled by animals, including humans, is an example of a chemical cue that 


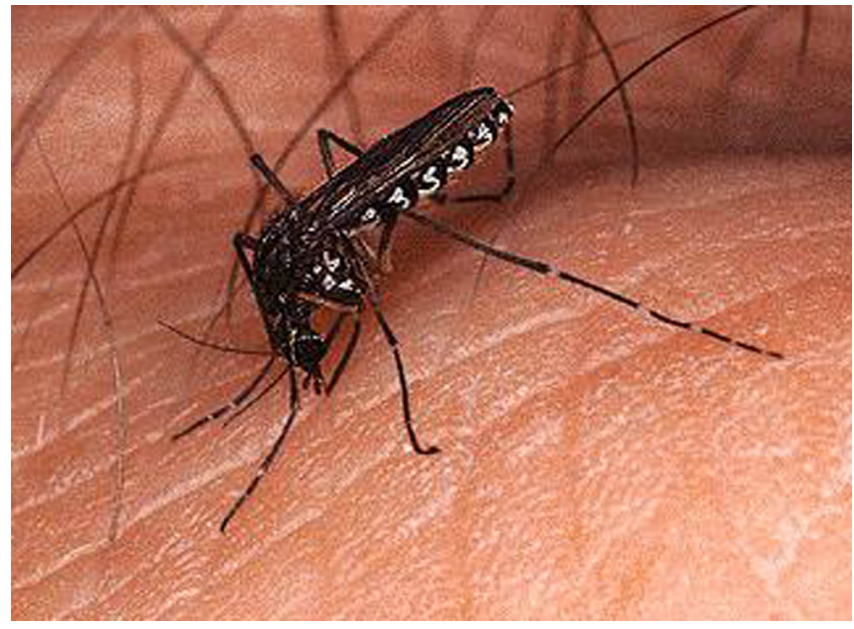

Figure 4. Black salt marsh mosquito. Credits: J. F. Butler, University of Florida

mosquitoes use to find their hosts. Repellents (discussed in the following section) work by "confusing" the mosquito, keeping it from landing on or biting the intended host.

Mosquitoes may be either "specialists," feeding only on birds, mammals, reptiles, or amphibians; or "generalists" that will readily attack whatever comes along. Others feed primarily on birds in the spring and then switch to mammals later in the season. Some mosquitoes will actively bite only at night, while others will readily feed during the day or at sunrise and sunset.

\section{Diseases Spread by Mosquitoes}

\section{West Nile Virus}

Culex pipiens is likely vector for $\mathrm{WNV}$; however, other mosquitoes have been implicated in transmission. The threat of WNV infection is most severe with the young children, the elderly, and immunocompromised people. The Centers for Disease Control (CDC) estimates that about $20 \%$ of people who are infected with the virus will develop West Nile fever. Symptoms of a mild infection include fever, headaches and body aches. Symptoms of severe infection include convulsions, muscle weakness, disorientation and coma. The time to disease symptoms is anywhere from 3 to 14 days. Mild symptoms may last a few days. Severe symptoms can last several weeks, and is life threatening. The CDC estimates that 1 in 150 people infected with West Nile will develop the severe disease. For more information see ENY-642, West Nile Virus (Rutledge et al. 2000)

\section{Eastern Equine Encephalomyelitis (EEE)}

Eastern Equine Encephalitis (EE) is a viral disease that may cause death in humans, horses and introduced birds such as pheasants and emus. EEE is caused by a viruse that is maintained in the wild bird population by the avian-feeding black-tailed mosquito (Culiseta melanura). The preferred habitat of the black-tailed mosquito is freshwater swamps shaded by heavy vegetation. See ENY-652, Eastern Equine Encephalis (Rey and Rutledge 2001) for more information.

\section{Heartworm}

Heartworm is transmitted to dogs via mosquitoes. Your veterinarian can prescribe a drug treatment that prevents the worms from reaching the adult stage in your dog. See ENY-628, Mosquito-borne Dog Heartworm Disease (Nayar 1998)

Other mosquito publications of interest can be accessed by typing "mosquitoes" in the EDIS search engine.

\section{How Do I Protect Myself from Bites?}

The best means of protection is to avoid mosquitoes by scheduling outdoor activities before or after peak mosquito activity, which is usually in the late afternoon and at dusk. Repellents containing diethyl toluamide (DEET) are effective in discouraging mosquitoes from biting. Drenching oneself in repellent is not necessary. You need only enough repellent to "confuse" the mosquito so it cannot detect a suitable spot to feed on you. There are repellents that boast 95 percent DEET content; however, a repellent of this concentration is unnecessary to provide adequate protection, may result in skin irritation, and is costly. Concentrations of 10 to 15 percent DEET are recommended for adults; products containing less than 8 percent are recommended for children. These concentrations are 
less prone to cause skin irritation, and they are more affordable. Repellents that are DEET-free, containing citronella or geraniol, are also effective. The geraniol containing product is relatively new and can be purchased at Zell's Hardware or at Fasst (www.fastkiller.com).

\section{How Can I Obtain Relief from Itching?}

Ointments that contain hydrocortisone, benzyl benzoate, or calamine can provide relief from itching. If you have questions about these products, be sure to discuss them with your health-care professional or pharmacist.

The saliva that is injected into the bite wound causes the itch from a mosquito bite. The saliva contains proteins that serve as an anticoagulant and help the mosquito to feed. The human immune system responds to the "foreign proteins," and the reaction is an itch.

\section{How Can I Control Mosquitoes?}

Effective and lasting mosquito control is complex, often requiring municipalities or local governments to legislate control efforts. You may not have containers with standing water, but your neighbor may, or water may be collecting in a ditch somewhere in the neighborhood. There are things homeowners can do to help prevent mosquito infestations. Three methods of prevention are to sanitize to reduce breeding sites, to use physical methods of control, and to use control products.

\section{Sanitation}

The first step in sanitizing is to eliminate the breeding sites listed above. It is also important to manage vegetation because adult mosquitoes rest on dense vegetation during the day. Cut tall weeds, and keep shrubs and trees trimmed away from the house to increase air circulation.

Other steps you can take include the following:

- Clean debris from rain gutters.

- Eliminate standing water on and around structures such as flat roofs, air conditioner units, and leaky pipes and faucets.

- Eliminate seepage from cisterns, cesspools, and septic tanks.

- Change the water in birdbaths and wading pools weekly.

- Change the water in pet bowls daily.

- Water plants and lawns so that water is not left standing for several days.

- Stock ornamental ponds with Gambusia fish that feed on mosquito larvae.

- Encourage other insects such as dragonfly (nymphs) and certain aquatic beetles that feed on mosquitoes.

\section{Physical Control}

Physical control methods focus on excluding mosquitoes from the indoors and include the following:

- Install screens that are 16 to 18 mesh.

- Screen the chimney and other vent flues during mosquito season. (Remove screens during winter.)

- Repair broken screens on windows, doors, and porches.

- Keep doors closed if not screened.

- Caulk cracks and crevices where insects can enter.

- Use a fly swatter for the occasional mosquito that is inside.

\section{Control Products and Materials}

There are a number of products and materials that can be used alone or in combination to control mosquitoes. These control methods can be directed toward either larvae or adults and therefore are categorized as larvicides or adulticides.

\section{Larvicides}


Products to control larvae ("wrigglers") include the following:

- Bacillus thuringiensis var. israelensis (B.t.i.) that is commercially available as Bactomos, Teknar, and Vectobac. B.t.i. can also be purchased as "mosquito dunks" that can be used in water that cannot be drained, such as unused swimming pools and retention ponds. B.t.i. is considered a "biological" method and poses a minimal threat to nontarget organisms.

- Insect growth regulators such as methoprene can be used in water when fish are present. Methoprene acts by preventing the larvae from becoming adults. Timing is important when applying methoprene as a liquid because it degrades rapidly when exposed to sunlight. Commercial formulations include Altosid in liquid and briquets. Briquets are reported to last up to 30 days under field conditions.

- Malathion, temephos (abate), and pyrethrins are also commonly used larvicides. Read the label and hazard statements concerning fish and other aquatic life before using these larvicides to determine whether these chemicals are appropriate to use in your situation.

\section{Adulticides}

Products to control adult mosquitoes include the following:

- Foggers. yard foggers typically contain pyrethrins. They can be set off shortly before outside activity and will provide temporary relief from mosquitoes.

- Sprays. Treat shrubs and the lower branches of trees where mosquitoes rest. Use insecticides registered for flying insects but that will not harm plants -- for example, certain formulations of malathion, permethrin, pyrethrins, and chlorpyrifos.

- Ultra-low volume (ULV) applications. ULV applications require special equipment that local governments usually control. 
Table 1. Insecticides labeled for genneral Homeowner Use, including mosquitoes.

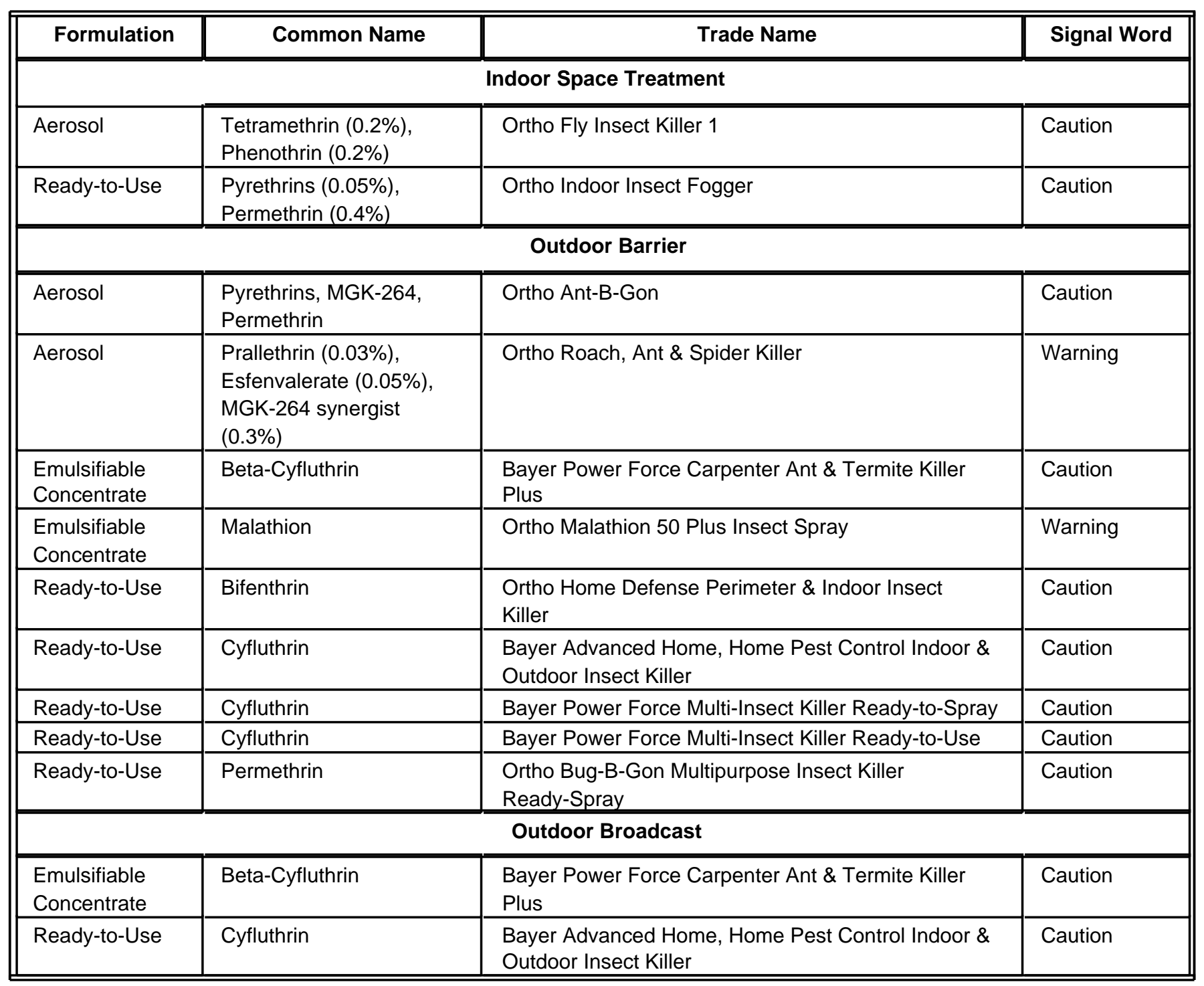

Table 2. Insecticides labeled for general Commercial Use, including mosquitoes.

\begin{tabular}{||l|l|l|l||}
\hline \hline \multicolumn{1}{|||}{ Formulation } & \multicolumn{1}{|c||}{ Common Name } & \multicolumn{1}{c||}{ Trade Name } \\
\hline \multicolumn{2}{|c||}{ Indoor Space Treatment } \\
\hline Aerosol & Pyrethrins and Others & $\begin{array}{l}\text { PT Clear Zone Metered Pyrethrum Spray } \\
\text { (Whitmire Micro-gen) }\end{array}$ & Caution \\
\hline Aerosol & Pyrethrins and Others & $\begin{array}{l}\text { PT Pro-Control } \\
\text { (Whitmire Micro-gen) }\end{array}$ & Caution \\
\hline Aerosol & Pyrethrins and Others & $\begin{array}{l}\text { PT Pro-Control Plus } \\
\text { (Whitmire Micro-gen) }\end{array}$ & Caution \\
\hline Aerosol & $\begin{array}{l}\text { Pyrethrins (0.5\%), PBO } \\
(4.0 \%)\end{array}$ & $\begin{array}{l}\text { PT P.I. Contact Insecticide } \\
\text { (Whitmire Micro-gen) }\end{array}$ & Caution \\
\hline $\begin{array}{l}\text { Emulsifiable } \\
\text { Concentrate }\end{array}$ & $\begin{array}{l}\text { Prallethrin } \\
\text { (Whitmire Micro-gen) }\end{array}$ & Caution \\
\hline \hline
\end{tabular}


Table 2. Insecticides labeled for general Commercial Use, including mosquitoes.

\begin{tabular}{|c|c|c|c|}
\hline Formulation & Common Name & Trade Name & Signal Word \\
\hline $\begin{array}{l}\text { Emulsifiable } \\
\text { Concentrate }\end{array}$ & Pyrethrins & $\begin{array}{l}\text { Kicker } \\
\text { (Aventis) }\end{array}$ & Caution \\
\hline $\begin{array}{l}\text { Emulsifiable } \\
\text { Concentrate }\end{array}$ & Pyrethrins & $\begin{array}{l}\text { PT ULD BP-300 } \\
\text { (Whitmire Micro-gen) }\end{array}$ & Caution \\
\hline $\begin{array}{l}\text { Emulsifiable } \\
\text { Concentrate }\end{array}$ & Pyrethrins and Others & $\begin{array}{l}\text { PT ULD BP-100 } \\
\text { (Whitmire Micro-gen) }\end{array}$ & Caution \\
\hline $\begin{array}{l}\text { Emulsifiable } \\
\text { Concentrate }\end{array}$ & $\begin{array}{l}\text { Pyrethrins }(0.5 \%), \text { PBO } \\
(5.0 \%)\end{array}$ & $\begin{array}{l}\text { PT ULD BP-50 } \\
\text { (Whitmire Micro-gen) }\end{array}$ & Caution \\
\hline $\begin{array}{l}\text { Emulsifiable } \\
\text { Concentrate }\end{array}$ & $\begin{array}{l}\text { Pyrethrins (1.0\%), PBO } \\
(5.0 \%)\end{array}$ & $\begin{array}{l}\text { Pyrenone } 100 \\
\text { (Aventis) }\end{array}$ & Caution \\
\hline $\begin{array}{l}\text { Emulsifiable } \\
\text { Concentrate }\end{array}$ & $\begin{array}{l}\text { Pyrethrins (2.5\%), PBO } \\
(12.5 \%)\end{array}$ & $\begin{array}{l}\text { Synerol Insecticide } \\
\text { (Aventis) }\end{array}$ & Caution \\
\hline $\begin{array}{l}\text { Emulsifiable } \\
\text { Concentrate } \\
\end{array}$ & $\begin{array}{l}\text { Pyrethrins }(0.5 \%), \text { PCO } \\
(5.0 \%)\end{array}$ & $\begin{array}{l}\text { Pyrenone } 50 \\
\text { (Aventis) }\end{array}$ & Caution \\
\hline \multicolumn{4}{|c|}{ Outdoor Barrier } \\
\hline $\begin{array}{l}\text { Emulsifiable } \\
\text { Concentrate }\end{array}$ & Bifenthrin & $\begin{array}{l}\text { Talstar F Termiticide/Insecticide } \\
\text { (FMC) }\end{array}$ & Caution \\
\hline $\begin{array}{l}\text { Emulsifiable } \\
\text { Concentrate } \\
\end{array}$ & Bifenthrin & $\begin{array}{l}\text { Talstar Termiticide/Insecticide } \\
\text { (FMC) }\end{array}$ & Caution \\
\hline $\begin{array}{l}\text { Emulsifiable } \\
\text { Concentrate }\end{array}$ & Cypermethrin & $\begin{array}{l}\text { Cynoff EC } \\
\text { (FMC) }\end{array}$ & Caution \\
\hline $\begin{array}{l}\text { Emulsifiable } \\
\text { Concentrate }\end{array}$ & Cypermethrin & $\begin{array}{l}\text { Cynoff Power Spray Insecticide } \\
\text { (FMC) }\end{array}$ & Warning \\
\hline $\begin{array}{l}\text { Emulsifiable } \\
\text { Concentrate }\end{array}$ & Cypermethrin & $\begin{array}{l}\text { Cynoff WSB } \\
\text { (FMC) }\end{array}$ & Warning \\
\hline $\begin{array}{l}\text { Emulsifiable } \\
\text { Concentrate }\end{array}$ & Cypermethrin & $\begin{array}{l}\text { Prevail FT Termitcide } \\
\text { (FMC) }\end{array}$ & Caution \\
\hline $\begin{array}{l}\text { Emulsifiable } \\
\text { Concentrate }\end{array}$ & Deltamethrin & $\begin{array}{l}\text { Suspend SC Insecticide } \\
\text { (Aventis) }\end{array}$ & Caution \\
\hline \multicolumn{4}{|c|}{ Outdoor Broadcast } \\
\hline $\begin{array}{l}\text { Emulsifiable } \\
\text { Concentrate }\end{array}$ & Bifenthrin & $\begin{array}{l}\text { Talstar F Termiticide/Insecticide } \\
\text { (FMC) }\end{array}$ & Caution \\
\hline $\begin{array}{l}\text { Emulsifiable } \\
\text { Concentrate }\end{array}$ & Bifenthrin & $\begin{array}{l}\text { Talstar Termiticide/Insecticide } \\
\text { (FMC) }\end{array}$ & Caution \\
\hline
\end{tabular}

Table 3. Mosquito control products for professional use--adulticides.

\begin{tabular}{|c|c|c|}
\hline Product Name & Active Ingredient & Manufacturer \\
\hline Anvil@ 2+2 ULV & Sumithrin, PBO & Clarke \\
\hline Anvil® 10+10 ULV & Sumithrin, PBO & Clarke \\
\hline Biomist $\circledast$ 1.5+7.5 ULV & Permethrin & Clarke \\
\hline Flit' $13.3 \mathrm{EC}$ & Permethrin & Clarke \\
\hline Fyfanon ULV & Malathion & Cheminova \\
\hline
\end{tabular}


Table 3. Mosquito control products for professional use--adulticides.

\begin{tabular}{||l|l|l||}
\hline \hline \multicolumn{1}{|c|}{ Product Name } & \multicolumn{1}{|c||}{ Active Ingredient } & \multicolumn{1}{c||}{ Manufacturer } \\
\hline Kontrol 30 & Permethrin, PBO & Univar \\
\hline Masterline Kontrol 4-4 & Permethrin, PBO & Univar \\
\hline \hline
\end{tabular}

Table 4. Mosquito control products for professional use--larvicides

\begin{tabular}{||l|l|l||}
\hline \hline \multicolumn{1}{|c|}{ Product Name } & \multicolumn{1}{|c||}{ Active Ingredient } & \multicolumn{1}{c||}{ Manufacturer } \\
\hline Abate 4-E & Temephos & Clarke Mosquito Control Products \\
\hline $5 \%$ Skeeter Abate & Temephos & Clarke Mosquito Control Products \\
\hline Altosid Liquid Larvicide & Methoprene & Wellmark-Zoecon \\
\hline Altosid XR-G, granular & Methoprene & Wellmark-Zoecon \\
\hline Altosid XR, briquets & Methoprene & Wellmark-Zoecon \\
\hline Altosid, briquets & Methoprene & Wellmark-Zoecon \\
\hline Bactimos Briquets & Bacillus thurgingiensis Berliner var. israelensis & Summit \\
\hline VectoBac 12AS & Bacillus thurgingiensis var. israelensis & Valent BioSciences Corporation \\
\hline VectoBacG & Bacillus thurgingiensis var. israelensis & Valent BioSciences Corporation \\
\hline VectoLex CG & Bacillus sphaericus Serotype H5a5b, strain 2362 & Valent BioSciences Corporation \\
\hline VectoLex WDG & Bacillus sphaericus Serotype H5a5b, strain 2362 & Valent BioSciences Corporation \\
\hline VectoLex WSP & Bacillus sphaericus Serotype H5a5b, strain 2362 & Valent BioSciences Corporation \\
\hline \hline
\end{tabular}

